\title{
The Effect of Insurance Activity on per Capita Income in the Southern Mediterranean: An Empirical Analysis Using Jordan as a Case Study
}

\author{
Metri Mdanat' ${ }^{1}$ Hamad A. Kasasbeh ${ }^{2}$, Ismail Abushaikha ${ }^{3}$ \\ ${ }^{1}$ Management Science Department, German Jordanian University, Madaba, Jordan \\ ${ }^{2}$ Department of Banking and Finance, Al-Zaytoonah University of Jordan, Amman, Jordan \\ ${ }^{3}$ Logistic Science Department, German Jordanian University, Madaba, Jordan \\ Email: metri.mdanat@gju.edu.jo, Hamad.k@zuj.edu.jo, ismail.abushaikha@gju.edu.jo
}

How to cite this paper: Mdanat, M., Kasasbeh, H.A. and Abushaikha, I. (2019) The Effect of Insurance Activity on per Capita Income in the Southern Mediterranean: An Empirical Analysis Using Jordan as a Case Study. Theoretical Economics Letters, 9, 912-928.

https://doi.org/10.4236/tel.2019.94059

Received: February 14, 2019

Accepted: April 15, 2019

Published: April 18, 2019

Copyright $\odot 2019$ by author(s) and Scientific Research Publishing Inc. This work is licensed under the Creative Commons Attribution International License (CC BY 4.0).

http://creativecommons.org/licenses/by/4.0/

\begin{abstract}
This study examines the effects of insurance activity on per capita income in the case of a southern Mediterranean country (Jordan) over the period 1990-2017 using an Autoregressive Distributed Lag (ARDL) cointegration analysis to describe the dynamic long relationship between per capita income and insurance activity. It provides empirical evidence that insurance sector activity, measured by insurance investment, had a negative and significant effect on per capita income in Jordan during the studied period. However, it was also found that the negative effects of insurance sector activity on growth were limited by other economic policies which hamper per capita growth, such as inflation. The study recommends that more diversification of insurance products is necessary and that new markets need to be explored in order for insurance companies in southern Mediterranean countries to compete in international markets. Although there are several agreements between Mediterranean countries, negotiations on minimizing restrictions on insurance company activities could be done through easing procedures, reducing costs and enhancing future economic relations by exploring new economic relations or by building on current protocol and trade agreements. Furthermore, the study notes that policymakers in southern Mediterranean countries must aim for a well-developed insurance sector so that its activity can contribute to economic growth through mobilizing national saving to finance long-term investment projects. More attention should be paid throughout the region to insurance sector activities while conducting financial sector analysis and macroeconomic policy design.
\end{abstract}

\section{Keywords}

Insurance Sector, Per Capita Income, Mediterranean Countries, ARDL 


\section{Introduction}

The insurance sector plays a vital role in the economy, as insurance companies are large investors and their activities can be affected by interest rates and risk assets. For instance, rising interest rates, and higher investment income are among the positive factors that appear to be bolstering insurance sector activities in 2018 [1]. Insurance sector activities are linked with those of financial institutions and have been found to be influenced by the same external and internal shocks, including interest rate fluctuations, asset price regulation, and changing international prices. In addition, the role of the insurance sector is similar to that of financial institutions in serving the needs of both businesses and households [2].

It is notable that insurance actors around the world share the objective of helping to achieve sustainable economic growth. This is particularly true for advanced economies, where the insurance sector is more significant than in less developed economies such as those in Mediterranean countries. For instance, advanced economies spend around $10 \%$ of their GDP on insurance while for developing economies this value is less than 4\% [3]. Empirical and theoretical studies of some countries indicate a positive relationship between insurance sector activity and economic growth, as growth is boosted by the mobilization of national savings to finance productive investment projects and by the effect of insurance activities in fostering financial stability, thus promoting trade and commerce activity [4]. Thus, there are several means through which a financial market and its constituents, such as banks, insurance companies, and pension funds, affect economic growth. Insurance sector activities influence economic growth by mobilizing savings through the accumulation of capital, transforming risk and reducing losses, efficiently allocating resources and capital in the economy, and increasing investment [5] [6] [7]. However, there is a distinct difference between the ways in which life insurance and non-life insurance impact accumulation of capital and investment: generally speaking, life insurance activity mobilizes capital and encourages long-term investments while non-life insurance activity results in short-term investments [8].

Studies of the relationship between insurance activity and economic growth in Mediterranean countries are limited in both number and scope. Most studies focus on the impact of insurance services on the financial system or the relationship between the size and performance of the insurance sector with economic development. The importance of insurance sector activity and its direct impact on per capita income have been considered, but within narrow limits. There has been extensive research into the contributions of banks and financial markets to growth in developing countries, but no empirical research has dealt specifically with the effect of insurance sector activity on per capita income in the case of Mediterranean countries. A study by [9] concludes that the importance of financial intermediaries such as banks and insurance companies in economic development is poorly understood, an observation which remains true 
today in Jordan and other Mediterranean countries. Therefore enhancing relations between Mediterranean countries and Jordan is a mutual interest and benefit for both in terms of enhancing insurance related activities and its role in economic development. From the beginning, Jordan engaged in making strength relationship with other Mediterranean countries through the implementation of regional and sub-regional projects, which are considered valuable for the citizens of the entire region. Other benefits for Jordan and Mediterranean countries is to promote regional economic integration between the different Mediterranean countries in order to establish a Mediterranean free trade area, as well as to bring its regulatory procedures closer to other Mediterranean countries.

Thus, the objective of this study is to examine the extent to which insurance sector activity affects per capita income in Jordan and seeks to answer the following questions: To what extent does the insurance market promote growth? Is there a relationship between the insurance sector activity and per capita income? If so, what kind of insurance sector activities are desirable for promoting growth in Jordan and other Mediterranean countries?

The study offers an empirical test of the short and long run relationships between insurance activity and per capita income in Jordan by analysing country-specific time series data on insurance activity and its effect on growth in the context of a country with an unstable fiscal policy environment. The study finds that the relationship between insurance activity and per capita income in Jordan remains unfavourable to the promotion of economic growth. Further findings indicate that reform policies enacted by public and private sector entities in past decades have limited insurance sector activities' contributions to growth; therefore, new policies and approaches should be adopted to enable the insurance sector to assume a more effective role in the economy by assessing its interactions with other economic sectors.

This study has five sections in addition to this introduction. Section 2 reviews the literature on the effect of insurance sector activity on per capita income. Section 3 provides an overview of the evolution of insurance sector activities in some Mediterranean countries. Section 4 explains the methodology of the present study. Section 5 discusses its results, and Section 6 reviews the study's conclusions, policy implications and recommendations.

\section{Literature Review}

A review of the literature shows that numerous empirical studies have been conducted in non-Mediterranean countries on the relationship between insurance sector activity and economic growth and that their findings and conclusions differ significantly. Some authors conclude that there is a positive and significant correlation between insurance and economic growth [2] [8] [10] [11] and others have determined that it is a causal relationship [12] [13] [14], whereas a number of studies have found this relationship to be weak or non-existent [15] [16] [17]. Research is furthermore inconclusive and at times contradictory regarding the im- 
pact of different types of insurance on economic growth.

For instance, on the one hand, a study by [18] shows a positive impact on economic growth by non-life insurance activity as measured by penetration rate but finds a negative effect on economic growth as measured by density ${ }^{1}$. On the other hand, [11] found a positive and significant effect of aggregate and non-life insurance activity on economic growth, while the relationship was negative for life insurance activity. A recent study by [19] in six countries which differed in terms of economic development showed a significant positive relationship between insurance penetration and per capita income. The study also found a significant positive relationship with economic growth for non-life insurance as measured by net written premiums, penetration rate and density. Another study by [20] found that activity in the insurance sector in Tunisia had a significant positive effect on economic growth. A study by [21] showed that life insurance activity had a more significant effect on GDP per capita than did non-life insurance, while [9] found that both banking and life insurance penetration were robustly predictive of increased productivity in 55 countries.

In general, research into the effects of insurance on growth in developing countries remains limited, with confusing or contradictory results and inadequate statistical techniques. One such weakness that leads to non-robust results is the assumption that countries have the same insurance structure, regulations, and characteristics. For example, according to [22], variations in premium rates between different countries does not allow for a complete view of insurance output and failure to consider such variations can lead to misleading results.

Whether insurance activities lead to economic growth or not is a matter of ongoing debate in literature, but literature generally agrees about certain factors that impact this relationship; for example, it is generally agreed that life insurance leads to increased saving, mobilizes capital, and increases long-term investment, while non-life insurance increases short-term investment [8]. Other such factors include the cultural or legal environment, as well as the development of financial regulations in the country.

We can conclude from this brief review of the literature that research into economic growth and insurance activity has had mixed results and that there remains much room for debate regarding the impact of both life and non-life insurance on growth, depending on national conditions, model specifications and estimation techniques. A fair assessment would be that empirical studies have raised a range of issues that must be considered but have provided no definitive answers in the case of the Mediterranean region.

\section{Evolution of Insurance Sector Activities}

Insurance sector activities in the Mediterranean region can be divided into two main types: life and non-life insurance. The former accounts for a small proportion of total activity in Mediterranean countries, whose economies rely more on

${ }^{1}$ The main reasons for such a negative relationship are related to the sample of countries included in this study and the level of development of the insurance business in the OECD countries. 
the latter. Life insurance premiums are perceived as saving deposits that are managed by insurers and provide lump-sum payments to the insured person or beneficiaries in the case of survival within the agreed period. Non-life insurance premiums, on the other hand, are perceived as the return for successful risk assessment.

At the end of the last century, life insurance was relatively undeveloped in all of Europe's emerging markets, where its penetration (direct gross premiums / GDP) in 1998 was only $0.43 \%$ [23]. The same can still be said to describe insurance sector activities in the Mediterranean region. A recent report for Ernst and Young shows that regional penetration remains lower than in most of the world's emerging markets and that life insurance and savings make negligible contributions [24].

In some Mediterranean countries, regulators restrict some insurance activities. For instance, in Jordan, Egypt, and Turkey, banks face restrictions on engaging in insurance activities. In Morocco, banks are permitted to engage in insurance activities to some extent, while in Syria and Algeria banks are strictly prohibited from dealing in insurance activities in all forms [25]. As a result, the presence of non-banking financial companies such as insurance companies is modest in most Mediterranean countries.

This trend is not exclusive to Mediterranean countries. In Chile, for instance, the insurance sector has the highest penetration and density in Latin America with a penetration rate of $3.6 \%$ of GDP and a density of $352.7 \mathrm{USD} /$ capita in 2017 [26]. On the other hand, despite being a developing country, Poland's insurance market is moderately developed, as shown by the penetration at $3.1 \%$ and density at 435 USD and life insurance plays a less significant role in the market as a whole [27].

Insurance activities in southern Mediterranean countries remain well below the average world level of about $6.3 \%$. Furthermore, as Figure 1 shows, this gap is also accompanied by a trend for the Mediterranean in which life insurance activities have less penetration than non-life insurance activities, which stands in contrast to the world trend. In Jordan, life insurance is below the average of the southern Mediterranean countries while non-life insurance is higher.

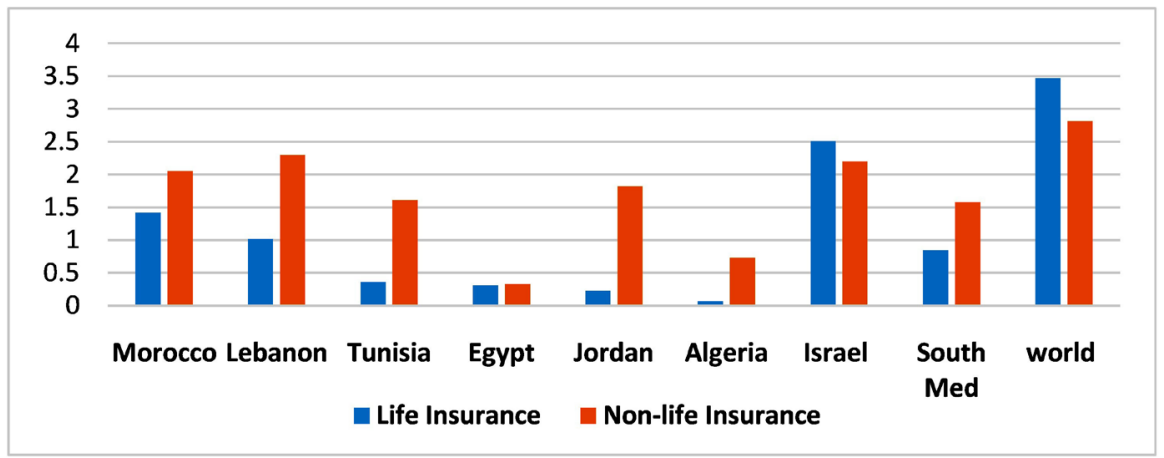

Source: Swiss Re Institute, 2017 [28].

Figure 1. Insurance penetration (premiums as \% of GDP in 2016). 


\section{Methodology and Data}

To examine the relationship between insurance sector activity and per capita income for the period 1990-2017, we employed an Autoregressive Distributed Lag (ARDL) cointegration technique or bound test to describe the dynamic long-run relationships of variables. The ARDL model has several advantages over other models; it can deal with different integration orders such as $\mathrm{I}(0), \mathrm{I}(1)$, or a combination of both and is more efficient if the sample data size is small. Annual data was obtained from the Central Bank of Jordan [29], the Swiss Re Institute [28], the Ministry of Finance [30], and the Jordan Insurance Federation [31]. In this study, we estimate two models of the co-integration ARDL by taking into account insurance activity such as insurance investment and penetration rate. To determine the long run relationships of variables, we construct two models. The first model in equation 1 describes insurance investment while the second model in equation 2 describes the insurance penetration rate as proxies for insurance activity. In both models (Model 1 and model 2) dependent variable is per capita income growth (Percapit), Both models are specified in an AutoRegressive Distributed lag (ARDL) as below:

Model 1:

$$
\begin{aligned}
\Delta \text { Lpercapit }_{t}= & \alpha_{0}+\sum_{i_{1}=1}^{l_{1}} \alpha_{1_{i}} \Delta L I R_{t-i_{1}}+\sum_{i_{1}=1}^{l_{2}} \alpha_{2_{i}} \Delta L I C I_{t-i_{2}}+\sum_{i_{2}=1}^{l_{3}} \alpha_{3_{i}} \Delta \text { LIL }_{t-i_{3}} \\
& +\sum_{i_{3}=1}^{l_{4}} \alpha_{4_{i}} \Delta L G E R_{t-i_{4}}+\sum_{i_{4}=1}^{l_{5}} \alpha_{5_{i}} \Delta \text { LTrade }_{t-i_{5}}+\beta_{1_{j}} \text { Lpercapit }_{t-j} \\
& +\beta_{2_{j}} \text { LIL }_{t-j}+\beta_{3_{j}} \text { LICI }_{t-j}+\beta_{4_{j}} \text { LGER }_{t-j}+\beta_{5_{j}} \text { LTrade }_{t-j}+\varepsilon_{t 1}
\end{aligned}
$$

Model 2:

$$
\begin{aligned}
\text { Lpercapit }_{t}= & a_{0}+\sum_{i_{1}=1}^{l_{1}} a_{1_{i}} \Delta L I R_{t-i_{1}}+\sum_{i_{1}=1}^{l_{2}} a_{2_{i}} \Delta L T P_{t-i_{2}}+\sum_{i_{2}=1}^{l_{3}} a_{3_{i}} \Delta L I L_{t-i_{3}} \\
& +\sum_{i_{3}=1}^{l_{4}} a_{4_{i}} \Delta L G E R_{t-i_{4}}+\sum_{i_{4}=1}^{l_{5}} a_{5_{i}} \Delta \text { LTrade }_{t-i_{5}}+\partial_{1_{j}} \text { Lpercapit }_{t-j} \\
& +\partial_{2_{j}} \text { LIL }_{t-j}+\partial_{3_{j}} \text { LTP }_{t-j}+\partial \partial_{4_{j}} \text { LGER }_{t-j}+\partial_{5_{j}} \text { LTrade }_{t-j}+\varepsilon_{t 2}
\end{aligned}
$$

where $\Delta$ shows the first difference, " $l$ "s and " $j$ "s are the lags, and " $P$ 's are the optimum lags, " $\alpha$. $\beta$.a.d”s are the coefficients, $L I R_{t}$ is the natural log of inflation rate, $L I C I_{t}$ is natural log of total investment of insurance companies, $L I L_{t}$ is the natural $\log$ of interest rate, $L G E R_{t}$ is natural log of government expenditure as a ratio of GDP, $L$ Trade $_{t}$ is natural log of trade openness as a ratio of GDP, $\alpha, \partial$, a and $\beta$ s are coefficients to be estimated and $\varepsilon t_{1}$ and $\varepsilon_{2}$ are the random error term.

Based on Equations (1) and (2) the following error correction models are specified as follow:

\section{Model 1:}

$$
\begin{aligned}
\Delta \text { Lpercapit }_{t}= & \alpha_{0}+\sum_{i_{1}=1}^{l_{1}} \alpha_{1_{i}} \Delta L I R_{t-i_{1}}+\sum_{i_{1}=1}^{l_{2}} \alpha_{2_{i}} \Delta L I C I_{t-i_{2}}+\sum_{i_{2}=1}^{l_{3}} \alpha_{3_{i}} \Delta L I L_{t-i_{3}} \\
& +\sum_{i_{3}=1}^{l_{4}} \alpha_{4_{i}} \Delta L G E R_{t-i_{4}}+\sum_{i_{4}=1}^{l_{5}} \alpha_{5_{i}} \Delta \text { Lrade }_{t-i_{5}}+\delta E C T_{t-1}+\mu_{t}
\end{aligned}
$$


Model 2:

$$
\begin{aligned}
\text { LLpercapit } t_{t}= & a_{0}+\sum_{i_{1}=1}^{l_{1}} a_{1_{i}} \Delta L I R_{t-i_{1}}+\sum_{i_{1}=1}^{l_{2}} a_{2_{i}} \Delta L T P_{t-i_{2}}+\sum_{i_{2}=1}^{l_{3}} a_{3_{i}} \Delta L I L_{t-i_{3}} \\
& +\sum_{i_{3}=1}^{l_{4}} a_{4_{i}} \Delta L G E R_{t-i_{4}}+\sum_{i_{4}=1}^{l_{5}} a_{5_{i}} \Delta L T r a d e_{t-i_{5}}+\delta E C T_{t-1}+\mu_{t}
\end{aligned}
$$

where $\alpha$ and a represent short run coefficients and $\delta$ the extent of disequilibrium correction.

All data were examined for the unit root and identified as stationary or I(1) to avoid misleading results. If the variables are non-stationary at level, and stationary at first differences, i.e. I(1), the ARDL model can be used provided that the variables integrated are of different orders ranging from level to first difference or both but not including second difference. The results of the ADF test in Table 1 and Table 2 confirm that the data is stationary at level except for per capita income and inflation rate. This result supports using the ARDL model to determine the long-run relationships among the variables.

Table 3 and Table 4 shows that the appropriate lag length for both models was

\begin{tabular}{|c|c|c|c|c|c|c|c|}
\hline \multicolumn{8}{|c|}{ At level } \\
\hline \multirow{3}{*}{ With constant \& trend } & & Percapita & IR & GE & TO & IL & ICI \\
\hline & t-Statistic & -3.282 & -5.199 & -3.564 & -1.923 & -2.718 & 0.142 \\
\hline & Prob. & 0.092 & 0.001 & 0.057 & 0.614 & 0.238 & 0.996 \\
\hline \multicolumn{8}{|c|}{ At first difference } \\
\hline \multirow{3}{*}{ With constant \& trend } & & $\mathrm{d}$ (percapita) & $\mathrm{d}(\mathrm{IR})$ & $\mathrm{d}(\mathrm{GE})$ & $\mathrm{d}(\mathrm{TO})$ & $d(I L)$ & $\mathrm{d}(\mathrm{ICI})$ \\
\hline & t-Statistic & -1.793 & -8.417 & -5.227 & -4.046 & -3.003 & -4.559 \\
\hline & Prob. & 0.6777 & 0.000 & 0.001 & 0.020 & 0.004 & 0.006 \\
\hline
\end{tabular}

Table 1. ADF unit root test results for model 1.

Note: MacKinnon (1996) one-sided p-values. Percapita is per capita income; IR is inflation rate; ICI is total investment of insurance companies; GER is government expenditure as a ratio of GDP; TO is trade openness; IL is interest rate.

\begin{tabular}{|c|c|c|c|c|c|c|c|}
\hline \multicolumn{8}{|c|}{ At level } \\
\hline \multirow{3}{*}{ With constant \& trend } & & Percapit & IR & GE & TO & $\mathrm{TP}$ & IL \\
\hline & t-Statistic & -3.282 & -5.199 & -3.564 & -1.923 & -2.264 & -2.718 \\
\hline & Prob. & 0.092 & 0.001 & 0.057 & 0.614 & 0.438 & 0.238 \\
\hline \multicolumn{8}{|c|}{ At first difference } \\
\hline \multirow{3}{*}{ With constant \& trend } & & $\mathrm{d}$ (percapit) & $\mathrm{d}(\mathrm{IR})$ & $\mathrm{d}(\mathrm{GE})$ & $\mathrm{d}(\mathrm{TO})$ & $\mathrm{d}(\mathrm{TP})$ & $\mathrm{d}(\mathrm{IL})$ \\
\hline & t-Statistic & -1.793 & -8.417 & -5.227 & -4.046 & -3.722 & -3.003 \\
\hline & Prob. & 0.6777 & 0.000 & 0.001 & 0.020 & 0.039 & 0.004 \\
\hline
\end{tabular}

Table 2. ADF unit root test results for model 2.

Note: MacKinnon (1996) one-sided p-values. Percapit is per capita income; IR is inflation rate; GER is government expenditure as a ratio of GDP; TO is trade openness; TP is total insurance penetration rate; IL is interest rate. 
chosen by using the Akaike Information Criterion (AIC), Schwarz Bayesian Criterion (SBC) or Hannan-Quinn Criterion (HQC). The results confirmed that the maximum lag length of the first model is 1 , and the maximum lag length for the second model is 2 .

Whether the variables are $\mathrm{I}(0), \mathrm{I}(1)$ or a combination of both, the ARDL model can be used and gives realistic and efficient estimates. The Cusum stability test in Figure 2 and Figure 3 shows that Cusum lies between the 5\% significance boundaries and that model 1 and model 2 are stable. This suggests that the variables in both models do not suffer from any structural instability over the period of study.

Table 3. VAR lag order selection criteria for model 1.

\begin{tabular}{ccccccc}
\hline Lag & LogL & LR & FPE & AIC & SC & HQ \\
\hline 0 & 50.914 & NA & 0.002 & -3.532 & -3.290 & -3.462 \\
1 & 59.059 & $12.531^{\star}$ & $0.001^{\star}$ & $-4.082^{\star}$ & $-3.791^{\star}$ & $-3.998^{\star}$ \\
2 & 59.241 & 0.266 & 0.0017 & -4.019 & -3.680 & -3.921
\end{tabular}

${ }^{*}$ indicates lag order selected by the criterion, LR: sequential modified LR test statistic, FPE: Final prediction error, AIC: Akaike information criterion, SC: Schwarz information criterion and HQ: Hannan-Quinn information criterion.

Table 4. VAR lag order selection criteria for model 2.

\begin{tabular}{ccccccc}
\hline Lag & LogL & LR & FPE & AIC & SC & HQ \\
\hline 0 & 161.5 & NA & $2.57 \mathrm{e}-13$ & -11.96 & -11.67 & -11.88 \\
1 & 308.1 & 214.2 & $5.65 \mathrm{e}-17$ & -20.47 & $-18.43^{\star}$ & -19.88 \\
2 & 366.6 & $58.5^{\star}$ & $1.66 \mathrm{e}-17^{\star}$ & $-22.20^{\star}$ & -18.43 & $-21.11^{\star}$ \\
\hline
\end{tabular}

${ }^{*}$ indicates lag order selected by the criterion, LR: sequential modified LR test statistic, FPE: Final prediction error, AIC: Akaike information criterion, SC: Schwarz information criterion and HQ: Hannan-Quinn information criterion.

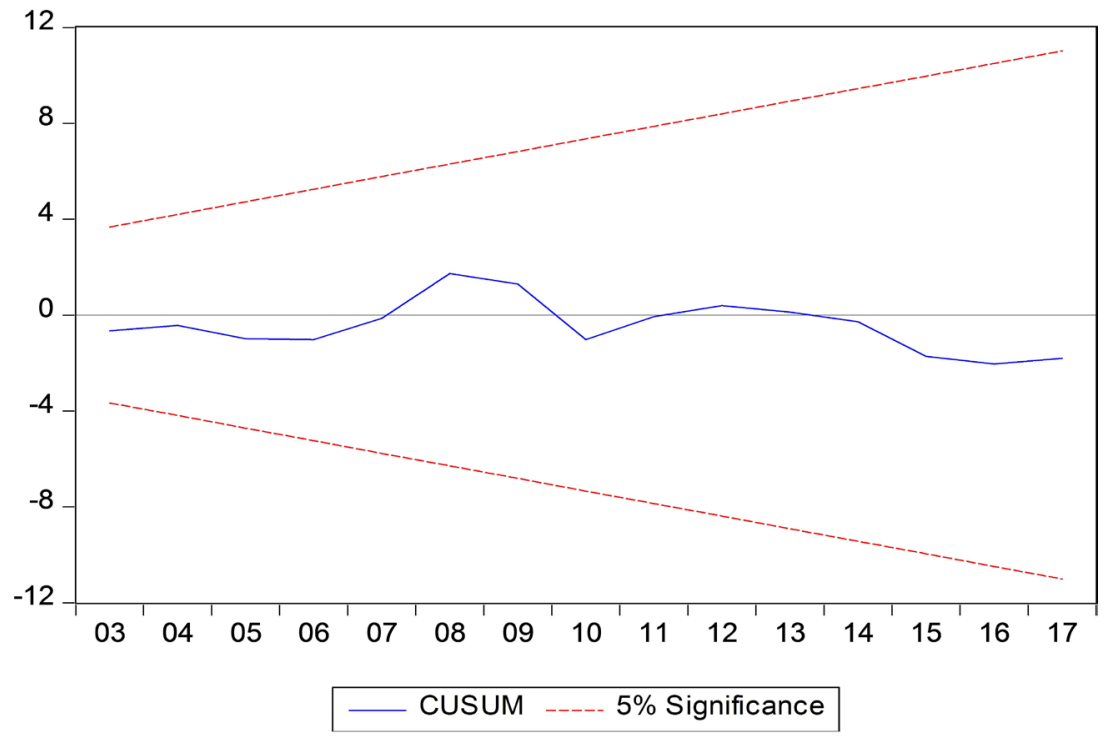

Figure 2. Cusum stability test results for model 1 . 


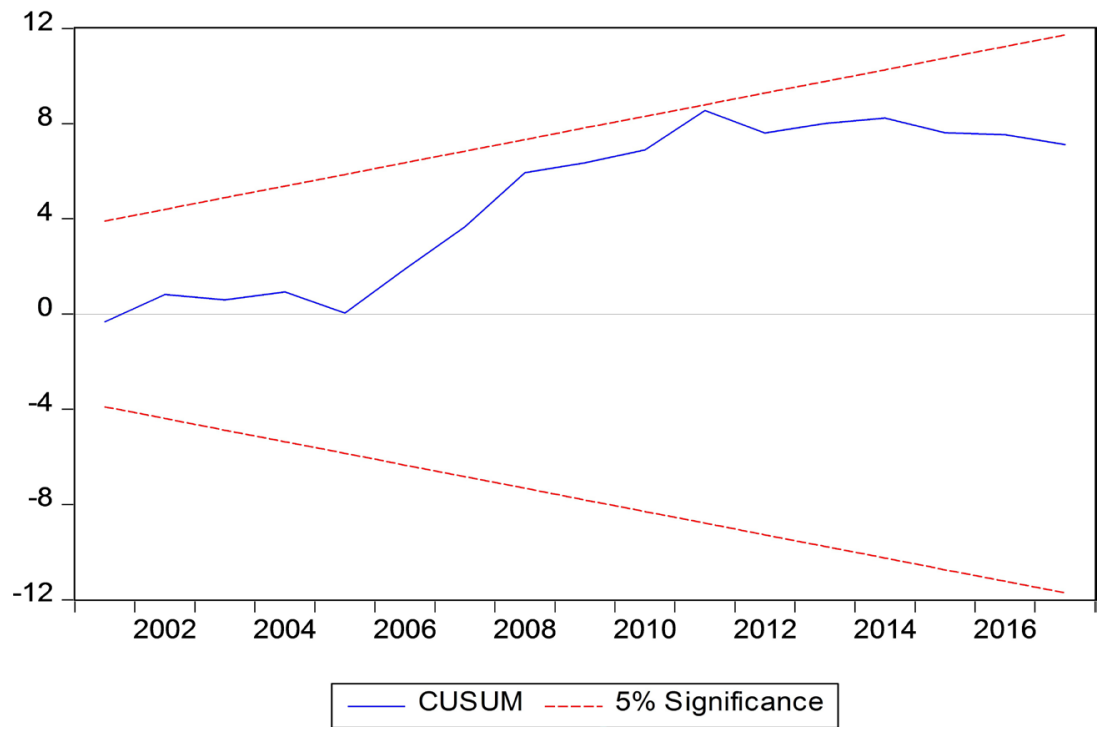

Figure 3. Cusum stability test results for model 2.

Table 5. Speed of adjustment.

\begin{tabular}{ccc}
\hline & Model 1 & Model 2 \\
\hline CointEq (-1) & -0.959 & -0.269 \\
t-Statistic & -9.493 & -23.641 \\
Prob. & 0.000 & 0.000 \\
\hline
\end{tabular}

Table 5 show the results of speed of adjustment equations for both models, it shows that the error correction term represented by CointEq $(-1)$ is -0.959 for model 1 and -0.269 for model 2 . This implies that about $96 \%$ of any movements into disequilibrium are corrected for within one year. Similarly, the result of model 2 implies that about 0.269 of any movements into disequilibrium are corrected for within one year. This suggests that the error correction model results of model 1 tends to cause insurance investment to converge to its long-run equilibrium faster than when using penetration rate as proxy for insurance activity. However, both models confirm the presence of long run equilibrium.

\section{Test Results}

The analysis of the relationship between per capita income and insurance sector investment was calibrated in the ARDL model 1 while the relationship between per capita income and insurance penetration rate in the ARDL model 2. The ARDL results of model 1 in Table 6 show that each independent variables and its one period lag is significant, with the exception of interest rate, trade openness and inflation at level.

The results of model 2 are shown in Table 7, it shows that most variables are significant with the exception of one period lag on penetration rate and trade openness.

To verify whether the residuals from model 1 and model 2 are serially uncorrelated, we use Breusch-Godfrey Serial Correlation LM Test. The results in Table 8 
Table 6. ARDL model 1 results.

\begin{tabular}{|c|c|c|c|c|}
\hline \multicolumn{5}{|c|}{ Dependent Variable: LNPERCAPIT } \\
\hline \multicolumn{5}{|c|}{ Selected Model: ARDL $(1,1,1,1,1,1)$} \\
\hline Variable & Coefficient & Std. Error & t-Statistic & Prob. ${ }^{*}$ \\
\hline LNPERCAPIT $(-1)$ & 0.041 & 0.200 & 0.207 & 0.839 \\
\hline LNINSINVES & -0.232 & 0.059 & -3.958 & 0.001 \\
\hline LNINSINVES $(-1)$ & 0.103 & 0.052 & 1.979 & 0.067 \\
\hline LNINTEREST & 0.069 & 0.121 & 0.572 & 0.576 \\
\hline LNINTEREST $(-1)$ & 0.265 & 0.140 & 1.890 & 0.078 \\
\hline LNTRADEOP & 0.045 & 0.104 & 0.432 & 0.672 \\
\hline LNTRADEOP $(-1)$ & 0.219 & 0.091 & 2.404 & 0.030 \\
\hline LNGOVEXP & 0.565 & 0.153 & 3.700 & 0.002 \\
\hline LNGOVEXP $(-1)$ & 0.442 & 0.134 & 3.302 & 0.005 \\
\hline INF & -0.249 & 0.355 & -0.702 & 0.493 \\
\hline $\operatorname{INF}(-1)$ & -1.139 & 0.250 & -4.554 & 0.000 \\
\hline $\mathrm{C}$ & 0.635 & 0.170 & 3.744 & 0.002 \\
\hline R-squared & 0.999 & \multicolumn{2}{|c|}{ Mean dependent var } & 7.509 \\
\hline Adjusted R-squared & 0.998 & \multicolumn{2}{|c|}{ S.D. dependent var } & 0.543 \\
\hline S.E. of regression & 0.024 & \multicolumn{2}{|c|}{ Akaike info criterion } & -4.314 \\
\hline Sum squared resid & 0.009 & \multicolumn{2}{|c|}{ Schwarz criterion } & -3.738 \\
\hline Log likelihood & 70.239 & \multicolumn{2}{|c|}{ Hannan-Quinn criter. } & -4.143 \\
\hline F-statistic & 1199.486 & \multicolumn{2}{|c|}{ Durbin-Watson stat } & 2.206 \\
\hline Prob(F-statistic) & & \multicolumn{2}{|c|}{0.000} & \\
\hline
\end{tabular}

${ }^{*}$ Note: $\mathrm{p}$-values and any subsequent tests do not account for model selection.

Table 7. ARDL model 2 results

\begin{tabular}{ccccc}
\hline \multicolumn{5}{c}{ Dependent Variable: LNPERCAPIT } \\
\hline \\
\multicolumn{4}{c}{ Selected Model: ARDL $(2,2,2,2,0,1)$} \\
\hline Variable & Coefficient & Std. Error & t-Statistic & Prob. $^{*}$ \\
\hline LNPERCAPIT $(-1)$ & 0.211 & 0.108 & 1.965 & 0.075 \\
LNPERCAPIT $(-2)$ & 0.520 & 0.073 & 7.076 & 0.000 \\
LNTOTPENT & -0.117 & 0.053 & -2.223 & 0.048 \\
LNTOTPENT $(-1)$ & -0.002 & 0.064 & -0.039 & 0.970 \\
LNTOTPENT (-2) & 0.161 & 0.051 & 3.176 & 0.009 \\
LNINTEREST & -0.147 & 0.066 & -2.220 & 0.048 \\
LNINTEREST $(-1)$ & -0.157 & 0.082 & -1.919 & 0.081 \\
LNINTEREST $(-2)$ & 0.115 & 0.063 & 1.809 & 0.098 \\
LNTRADEOP & -0.121 & 0.053 & -2.277 & 0.044 \\
\hline
\end{tabular}




\section{Continued}

\begin{tabular}{|c|c|c|c|c|}
\hline LNTRADEOP $(-1)$ & -0.040 & 0.050 & -0.794 & 0.444 \\
\hline LNTRADEOP $(-2)$ & 0.175 & 0.034 & 5.062 & 0.000 \\
\hline LNGOVEXP & 0.179 & 0.067 & 2.650 & 0.023 \\
\hline INF & 1.095 & 0.209 & 5.241 & 0.000 \\
\hline $\operatorname{INF}(-1)$ & 0.707 & 0.151 & 4.684 & 0.001 \\
\hline $\mathrm{C}$ & 0.312 & 0.285 & 1.095 & 0.297 \\
\hline R-squared & 1.000 & \multicolumn{2}{|c|}{ Mean dependent var } & 7.541 \\
\hline Adjusted R-squared & 1.000 & \multicolumn{2}{|c|}{ S.D. dependent var } & 0.527 \\
\hline S.E. of regression & 0.010 & \multicolumn{2}{|c|}{ Akaike info criterion } & -6.061 \\
\hline Sum squared resid & 0.001 & \multicolumn{2}{|c|}{ Schwarz criterion } & -5.335 \\
\hline Log likelihood & 93.790 & \multicolumn{2}{|c|}{ Hannan-Quinn criter. } & -5.852 \\
\hline F-statistic & 4874.244 & \multicolumn{2}{|c|}{ Durbin-Watson stat } & 2.837 \\
\hline Prob(F-statistic) & \multicolumn{4}{|c|}{0.000} \\
\hline
\end{tabular}

*Note: p-values and any subsequent tests do not account for model selection.

Table 8. Breusch-godfrey serial correlation LM test.

\begin{tabular}{ccccc}
\hline Model 1 & F-statistic & 0.776 & Prob. F $(2,13)$ & 0.393 \\
& Obs ${ }^{*}$ R-squared & 1.419 & Prob. Chi-Square (2) & 0.234 \\
Fodel 2 & F-statistic & 2.699 & Prob. F $(2,13)$ & 0.091 \\
& Obs ${ }^{*}$ R-squared & 9.748 & Prob. Chi-Square (2) & 0.008 \\
\hline
\end{tabular}

Table 9. Heteroskedasticity Test: Breusch-Pagan-Godfrey.

\begin{tabular}{ccccc}
\hline & F-statistic & 3.772 & Prob. F $(11,15)$ & 0.0095 \\
Model 1 & Obs * R-squared & 19.830 & Prob. Chi-Square (11) & 0.0477 \\
& Scaled explained SS & 4.716 & Prob. Chi-Square (11) & 0.944 \\
Fodel 2 & F-statistic & 0.368 & Prob. F $(11,15)$ & 0.959 \\
& Obs * R-squared & 8.294 & Prob. Chi-Square (11) & 0.874 \\
& Scaled explained SS & 1.279 & Prob. Chi-Square (11) & 1.000 \\
\hline
\end{tabular}

show that the F-statistic p-value of 0.393 for model 1 indicates that we fail to reject the null hypothesis is that the residuals are serially uncorrelated. We therefore conclude that the residuals are serially uncorrelated. In addition, we accept that residuals are serially correlated for model 2.

Similarly, we test for residual homoscedasticity in both models using BreuschPagan-Godfrey Test. The results in Table 9 indicate that model 1 is preferred over model 2, the F-statistic p-value of 0.0095 indicates that we fail to reject the null hypothesis is that the residuals are homoscedastic, while the results for model 2 indicate that the residuals are homoskedastic.

To continue with our analysis, all diagnostics test results indicate that using 
model 1 is more preferred over model 2 . The results of model 2 are shown in the Annexes. Therefore, we will continue with our analysis using model 1 and ignore model 2. We test for the presence of cointegration in model 1. The existence of the long-run relationship between per capita income and other variables in the model is tested by computing the Bound F-statistic. The results of the bound test are used to examine the relationship between the variables. Two critical values produced by [32] are equated with the F-statistics to establish cointegration. The results of the bound test for model 1 show that the estimated F-statistics value (11.3) is greater than the Pesaran upper bound of critical value $(3.35,3.79$ and 4.68$)$ at $10 \%, 5 \%$ and $1 \%$ significant value respectively. Therefore we reject the null hypothesis of no long relationship and accept that the long run relationship exists. Thus, the results in Table 10 confirm that a long-run relationship could exist between per capita income and independent variables.

The results of the long run relationship for model 1 is shown in Table 11. The coefficient of the insurance investment is negative and significant at $5 \%$ level, indicating that insurance investment had a negative effect on per capita income growth in the long-run. A $1 \%$ increase in insurance investment is associated with $0.13 \%$ decrease in per capita income in the long-run. Similarly, the association between inflation rate and per capita income had a negative relationship and significant at the 0.05 level in the long-run. The results also show that interest rate, trade openness and government expenditure had a positive relationship in the long-run with per capita income.

The results of short run relationship are shown in Table 12. Insurance investment had a negative relationship with per capita income in the short run and

Table 10. F-Bound Test results for model 1.

\begin{tabular}{cccccc}
\hline & Test Statistic & Value & Signif. & $\mathrm{I}(0)$ & $\mathrm{I}(1)$ \\
\cline { 2 - 6 } Model 1 & \multicolumn{5}{c}{ Asymptotic: $\mathrm{n}=1000$} \\
\cline { 2 - 6 } & F-statistic & 11.3 & $10 \%$ & 2.26 & 3.35 \\
& $\mathrm{k}$ & 5 & $5 \%$ & 2.62 & 3.79 \\
& & & $1 \%$ & 3.41 & 4.68 \\
\hline
\end{tabular}

Table 11. Results of long run relationship for model 1.

\begin{tabular}{ccccc}
\hline \multicolumn{5}{c}{ Levels Equation } \\
\hline & Case 3: Unrestricted Constant and No Trend & \\
\hline & \multicolumn{4}{c}{ Model 1 } \\
\hline Variable & Coefficient & Std. Error & t-Statistic & Prob. \\
\hline LNINSINVES & -0.134417 & 0.022562 & -5.957808 & 0.0000 \\
LNINTEREST & 0.348661 & 0.089843 & 3.880771 & 0.0015 \\
LNTRADEOP & 0.275352 & 0.112712 & 2.442980 & 0.0274 \\
LNGOVEXP & 1.050069 & 0.043419 & 24.18470 & 0.0000 \\
INF & -1.448992 & 0.416142 & -3.481967 & 0.0033 \\
\hline
\end{tabular}


Table 12. Results of error correction model for model 1.

\begin{tabular}{ccccc}
\hline \multicolumn{5}{c}{ ECM Regression } \\
\hline \multicolumn{5}{c}{ Case 3: Unrestricted Constant and No Trend } \\
\hline \multicolumn{5}{c}{ Model 1 } \\
\hline Variable & Coefficient & Std. Error & t-Statistic & Prob. \\
\hline C & 0.63 & 0.06 & 10.22 & 0.00 \\
D(LNINSINVES) & -0.23 & 0.04 & -5.95 & 0.00 \\
D(LNINTEREST) & 0.07 & 0.08 & 0.87 & 0.40 \\
D(LNTRADEOP) & 0.04 & 0.07 & 0.66 & 0.52 \\
D(LNGOVEXP) & 0.56 & 0.07 & 7.66 & 0.00 \\
D(INF) & -0.25 & 0.15 & -1.65 & 0.12 \\
CointEq $(-1)^{*}$ & -0.96 & 0.10 & -9.49 & 0.00 \\
\hline
\end{tabular}

${ }^{*}$ p-value incompatible with t-Bounds distribution.

significant at 5\% level in model 1. Furthermore, government expenditures had positive relationships in the short-run, while trade openness, inflation, and interest rates were found to be insignificant in the short-run. The CointEq $(-1)$ term is significant and negative, confirming the results of the bound test. The disequilibrium in the short run is corrected in the long-run at the adjustment speed of $96 \%$.

The inverse relationship of per capita income and insurance investment is due to individuals' behavioural intention to invest in short-term profitable instruments rather than in insurance, which needs more time to return a profit. In addition, most insurance companies in southern Mediterranean countries rely on non-life insurance that favoured short-term investment. Inflation affects per capita income negatively, significant at the 5\% level, in the long-run, because it will affect individuals' standard of living, thereby reducing per capita income. These findings are consistent with previous studies [2]. The results indicate that short run trade openness does not improve per capita income growth and that in the short-run trade openness initially had no effects on per capita income and then starts to be improved in the long-run [33].

\section{Conclusions, Policy Implication and Recommendations}

This study used an Autoregressive Distributed Lag (ARDL) to examine the short and long run relationships between per capita income and insurance sector activity in Jordan, measured by insurance penetration rate and insurance investment. The results confirm negative relationship of insurance investment with per capita income growth at a 0.05 significance level. However, the results also show that the negative effects of insurance sector activity on growth are impacted by other economic policies which hamper per capita growth, such as rising prices. Although insurance sector activity is negatively related to per capita growth, the positive impact on growth of increasing government expenditure 
tends to offset the negative effect of insurance investment on growth.

According to the results and analyses in this study, several issues should be considered by policymakers to develop the insurance sector's activities and increase its effect on economic growth in Jordan and other southern Mediterranean countries. First, government and regulator's restrictions on some insurance activities associated with inadequate procedures and regulations pose serious constraints to strengthening cooperation between southern Mediterranean countries in engaging in insurance activities. Second, the presence of insurance activities is modest in most Mediterranean countries and regulations have discouraged insurance companies to expand and trade with each other. Third, law restricts the much-needed diversification of insurance products and exploration of new markets necessary for insurance companies to compete in international markets. Although there are several agreements between Mediterranean countries, negotiations on minimizing restrictions on insurance companies could be done through easing procedures, reducing costs, and enhancing future economic relations by exploring new economic partnerships or building on current protocol and trade agreements. Furthermore, policymakers in southern Mediterranean countries must aim for a well-developed insurance sector and encourage life insurance so that its activity can contribute to economic growth through mobilizing national savings to finance long-term investment projects. Therefore, policymakers should give more attention to insurance sector activities while conducting financial sector analysis and macroeconomic policy design. For further research, economic analysis could be given greater resolution for individual variables concerning the impact of life insurance and non-life insurance activity. Further research is also needed to investigate the relationships between economic growth and insurance activities using a cross-country panel data analysis for other southern-Mediterranean countries.

\section{Conflicts of Interest}

The authors declare no conflicts of interest regarding the publication of this paper.

\section{References}

[1] Deloitte (2019) Insurance Outlook: Growing Economy Bolsters Insurers, but Longer-Term Trends May Require Transformation. Deloitte Center for Financial Services.

[2] Oke, O.M. (2012) Insurance Sector Development and Economic Growth in Nigeria. African Journal of Business Management, 6, 7016-7023. https://doi.org/10.5897/AJBM11.2853

[3] Outreville, J.F. (2013) The Relationship between Insurance and Economic Development: 85 Empirical Papers for a Review of the Literature. Risk Management and Insurance Review, 16, 71-122. https://doi.org/10.1111/j.1540-6296.2012.01219.x

[4] Phutkaradze, J. (2014) Impact of Insurance Market on Economic Growth in PostTransition Countries. International Journal of Management and Economics, 44, 
92-105.

[5] Skipper, H.D. (1997) Foreign Insurers in Emerging Markets: Issues and Concerns. Center for Risk Management and Insurance, Occasional Paper 97-2. http://rmictr.gsu.edu/Papers/FOREIGN.pdf

[6] Haiss, P. and Sümegi, K. (2007) The Relationship between Insurance and Economic Growth in Europe: A Theoretical and Empirical Analysis. Empirica, 35, 405-431.

[7] Zweifel, P. and Eisen, R. (2012) Insurance Economics. Springer, Berlin, New York, 451 p. https://doi.org/10.1007/978-3-642-20548-4

[8] Arena, M. (2006) Does Insurance Market Activity Promote Economic Growth? A Cross-Country Study of Industrialized and Developing Countries. World Bank Policy Research Paper 4098, World Bank, Washington DC.

[9] Webb, I.P., Grace, M.F. and Skipper, H.D. (2002) The Effect of Banking and Insurance on the Growth of Capital and Output. Centre for Risk Management and Insurance, Working Paper 02.

[10] Ward, D. and Zurburegg, R. (2000) Does Insurance Promote Economic Growth? Evidence from OECD Countries. Journal of Risk and Insurance, 67, 489-506. https://doi.org/10.2307/253847

[11] Kjosevski, J. (2011) Impact of Insurance on Economic Growth: The Case of the Republic of Macedonia. European Journal of Business and Economics, 4, 34-39.

[12] Kugler, M. and Ofoghi, R. (2005) Does Insurance Promote Economic Growth? Evidence from the UK. Working Paper, Department of Economics, University of Southampton.

[13] Eze, O.R. and Okoye, V. (2013) Analysis of Insurance Practices and Economic Growth in Nigeria: Using Co-Integration Test and Error Correction Model. Global Advanced Research Journal of Management and Business Studies, 2, 63-70.

[14] Chang, T., Lee, C.-C. and Chang, C.-H. (2014) Does Insurance Activity Promote Economic Growth? Further Evidence Based on Bootstrap Panel Granger Causality Test. The European Journal of Finance, 20, 1187-1320. https://doi.org/10.1080/1351847X.2012.757555

[15] Kjell, S. and Haiss, P. 2006) The Relationship of Insurance and Economic Growth: A Theoretical and Empirical Analysis. ECONOD Conference, Hong Kong.

[16] Nejad, H.R. and Kermani, S.A. 2012) The Relation between Insurance Development and Economic Growth in Iran. Finance Management, 47, 9079-9087.

[17] Omoke, P.C. (2011) Insurance Market Activity and Economic Growth: Evidence from Nigeria. Asian Economic and Financial Review, 1, 245-253.

[18] Zouhaier, H. (2014) Insurance and Economic Growth. Journal of Economic \& Sustainable Development, 5, 102-112.

[19] Mohyul Din, S., Regupathi, A. and Abu-Bakar, A. (2017) Insurance Effect on Economic Growth among Economies in Various Phases of Development. Review of International Business and Strategy, 27, 501-519. https://doi.org/10.1108/RIBS-02-2017-0010

[20] Ben Dhiab, L. and Jouili, T. (2015) Insurance and Economic Growth in Tunisia: A Theoretical and Empirical Analysis. Journal of Economics \& Sustainable Development, 6, 101-107.

[21] Cristea, M., Marcu, N. and Carstina, S. (2014) The Relationship between Insurance and Economic Growth in Romania Compared to the Main Results in Europe: A Theoretical and Empirical Analysis. Procedia Economics and Finance, 8, 226-235. https://doi.org/10.1016/S2212-5671(14)00085-9 
[22] Outreville, J.F. (1996) Life Insurance Markets in Developing Countries. Journal of Risk and Insurance, 63, 263-278.

[23] OECD (2000) Insurance Regulation and Supervision in OECD Countries. Asian Economies and CEEC and NIS Countries. OECD.

http://www.oecd.org/finance/insurance/1900939.pdf

[24] Russignan, L., Kachwalla, Z. and Kumar, N. (2017) Insurance Opportunities in the Middle East. Ernst \& Young Global Limited.

http://financedocbox.com/Insurance/74046258-Insurance-opportunities-in-the-mid dle-east.html

[25] Ayadi, R., Dabrowski, M. and Wulf, L. (2015) Economic and Social Development of the Southern and Eastern Mediterranean' Centre for European Studies. Springer, Berlin.

[26] OECD (2011) Chile: Review of the Insurance System.

[27] RAEX (2018) CEE Insurance Sector, Central and Eastern Europe Industry Research Insurance International Group of Rating Agencies.

[28] Swiss Re Institute (2017) World Insurance in 2016: The China Growth Engine Steams Ahead. Sigma 3/2017, Swiss Re Institute.

http://institute.swissre.com/research/overview/sigma/3_2017.html

[29] Central Bank of Jordan (2016) Annual Statistical Bulletin, Various Issues.

[30] Ministry of Finance (2017) Monthly Statistical Bulletin, Various Issues. Ministry of Finance, Amman.

[31] Jordan Insurance Federation (2016) Annual Reports, Various Issues. Amman.

[32] Pesaran, M.H., Shin, Y. and Smith, R.J. (2001) Bounds Testing Approaches to the Analysis of Level Relationships. Journal of Applied Econometrics, 16, 289-326. https://doi.org/10.1002/jae.616

[33] Arabiyat, T., Mdanat, M. and Samawi, G. (2019) Trade Openness, Inclusive Growth, and Inequality: Evidence from Jordan. The Journal of Developing Areas, 54, 123-136. 
Annexes

Annex 1: F-Bound Test Results for Model 2

\begin{tabular}{cccccc}
\hline & Test Statistic & Value & Signif. & $\mathrm{I}(0)$ & $\mathrm{I}(1)$ \\
\cline { 2 - 6 } Model 1 & \multicolumn{5}{c}{ Asymptotic: $\mathrm{n}=1000$} \\
\cline { 2 - 6 } & F-statistic & 64.041 & $10 \%$ & 2.26 & 3.35 \\
& $\mathrm{k}$ & 5 & $5 \%$ & 2.62 & 3.79 \\
& & & $1 \%$ & 3.41 & 4.68 \\
\hline
\end{tabular}

Annex 2: Results of Long Run Relationship for Model 2

\begin{tabular}{ccccc}
\hline \multicolumn{5}{c}{ Levels Equation } \\
\hline \multicolumn{5}{c}{ Case 3: Unrestricted Constant and No Trend } \\
\hline Variable & Coefficient & Std. Error & t-Statistic & Prob. \\
\hline LNTOTPENT & 0.155 & 0.285 & 0.542 & 0.599 \\
LNINTEREST & -0.703 & 0.310 & -2.265 & 0.045 \\
LNTRADEOP & 0.053 & 0.245 & 0.215 & 0.834 \\
LNGOVEXP & 0.666 & 0.095 & 6.974 & 0.000 \\
INF & 6.706 & 2.431 & 2.759 & 0.019 \\
\hline
\end{tabular}

\section{Annex 3: Results of Error Correction Model for Model 2}

\section{ECM Regression}

Case 3: Unrestricted Constant and No Trend

\begin{tabular}{|c|c|c|c|c|}
\hline \multicolumn{5}{|c|}{ Model 1} \\
\hline Variable & Coefficient & Std. Error & t-Statistic & Prob. \\
\hline $\mathrm{C}$ & 0.312 & 0.012 & 26.176 & 0.000 \\
\hline D(LNPERCAPITA $(-1))$ & -0.520 & 0.055 & -9.459 & 0.000 \\
\hline D(LNTOTPENT) & -0.117 & 0.029 & -3.982 & 0.002 \\
\hline D(LNTOTPENT $(-1))$ & -0.161 & 0.034 & -4.708 & 0.001 \\
\hline D(LNINTEREST) & -0.147 & 0.035 & -4.146 & 0.002 \\
\hline D(LNINTEREST $(-1))$ & -0.115 & 0.037 & -3.129 & 0.010 \\
\hline D(LNTRADEOP) & -0.121 & 0.029 & -4.218 & 0.001 \\
\hline D(LNTRADEOP $(-1))$ & -0.175 & 0.024 & -7.423 & 0.000 \\
\hline $\mathrm{D}(\mathrm{INF})$ & 1.095 & 0.068 & 16.099 & 0.000 \\
\hline CointEq $(-1)^{*}$ & -0.269 & 0.011 & -23.641 & 0.000 \\
\hline
\end{tabular}

${ }^{*}$ p-value incompatible with t-Bounds distribution. 